\title{
Anatomy of the lateral, diagonal and anterosuperior arterial branches of the left ventricle of the human heart
}

\author{
Anatomia dos ramos lateral, diagonal e ântero-superior no ventrículo esquerdo do coração humano
}

José Roberto ORTALE, José MECIANO FILHO, Ana Maria Ferreira PACCOLA, Júlia Guedes Pereira Garcia LEAL, Carolina Alves SCARANARI

RBCCV 44205-746

\section{Abstract}

Objective: The objective of the present report was to describe the lateral, diagonal and anterosuperior arterial branches in the epicardial adipose tissue of the left ventricle and to analyze their frequency and diameters according to the type of coronary circulation. The precious knowledge of these branches has surgical application in their revascularization or during the injection of the cardioplegic substances into these branches.

Method: Fifty hearts obtained at autopsy from adult cadavers were dissected and fixed in formalin and the left ventricle was divided into three thirds: superior, middle and inferior. The lateral branch originated from the circumflex branch, the diagonal branch from the division of the left coronary artery and the anterosuperior branch from the anterior interventricular branch in the superior third of the left ventricle. The length in the epicardium and the diameter of each branch were measured and the blood flow was related to the type of coronary circulation.

Results: The diameter of the lateral branch, present in $88 \%$ of the cases, ranged from 0.6 to $4.5 \mathrm{~mm}$ (mean: $2.1 \pm 0.7$ $\mathrm{mm})$. The diameter of the diagonal branch, present in $50 \%$ of cases, ranged from 1.0 to $3.8 \mathrm{~mm}$ (mean: $2.2 \pm 0.7 \mathrm{~mm}$ ). The diameter of the anterosuperior branch, present in $84 \%$ of cases, ranged from 1.0 to $4.1 \mathrm{~mm}$ (mean: $2.5 \pm 0.8 \mathrm{~mm}$ ). We detected $30 / 50(60 \%)$ cases of dominance of the right coronary artery, $14 / 50(28 \%)$ cases of the balanced type, and 6/12 (12\%) cases of dominance of the left coronary artery. Mean blood flow in the anterosuperior branch presented a decreasing value in the following types: dominance of the right coronary artery, balanced and dominance of the left coronary artery. Conversely, the lateral branch showed respectively increasing values, while the diagonal branch presented a greater flow in the balanced type.

Conclusion: The results demonstrated the complementarity of the lateral, diagonal and anterosuperior arterial branches, as well as the correlation among these branches with the following types of coronary circulation: right dominance, balanced and left dominance.

Descriptors: Heart, anatomy \& histology. Coronary circulation.
Work performed in theLife Sciences Center, Catholic Pontifical University in Campinas, Campinas-SP.

Correspondence address: Dr. José Roberto Ortale. Centro de Ciências da Vida, Pontifícia Universidade Católica de Campinas - Campus II.Av. John Boyd Dunlop, s/n ${ }^{\circ}$ - Jardim Ipaussurama. Campinas, SP CEP 13059-900. Tel: (0xx19) 3729-8466. Fax: (0xx19) 3729-8517. E-mail: ortalejr@uol.com.br
Article received in March, 2005 Article accepted in May, 2005 


\section{Resumo}

Objetivo: O objetivo deste trabalho é a descrição dos ramos lateral, diagonal e ântero-superior, no tecido adiposo epicárdico do ventrículo esquerdo, e a análise da freqüência e do diâmetro destes, conforme o tipo de circulação coronariana. $O$ conhecimento preciso desses ramos tem aplicabilidade na abordagem cirúrgica para a sua revascularização ou durante a injeção de substâncias cardioplégicas nos mesmos.

Método: Dissecados 50 corações obtidos de necropsias de adultos, fixados em solução de formol e o ventrículo esquerdo dividido em três terços: superior, médio e inferior. $O$ ramo lateral originou-se do ramo circunflexo; o ramo diagonal, do ponto de divisão da artéria coronária esquerda e o ramo ânterosuperior, do ramo interventricular anterior no terço superior do ventrículo esquerdo. Para cada ramo foram medidos o comprimento no epicárdio e o diâmetro, além disso foi relacionado o fluxo sangüíneo com o tipo de circulação coronariana.

Resultados: O diâmetro do ramo lateral, presente em $88 \%$ dos casos, variou de 0,6 a $4,5 \mathrm{~mm}$ (média $2,1 \pm 0,7 \mathrm{~mm}$ ). $\mathrm{O}$

\section{INTRODUCTION}

Initially, let us present the concepts adopted in respect to the coronary artery branches of the anterior face of the left ventricle, the focus of the present study.

The lateral branch originates from the circumflex branch of the left coronary artery, before the root of the left marginal branch.

The diagonal branch is one of the terminal branches of the left coronary artery, as well as the circumflex and anterior interventricular branches, when it splits into three or four branches.

The anterosuperior branch of the left ventricle is the one that originates from the anterior interventricular branch in the upper third of the left ventricle

Detailed knowledge about the coronary artery branches has already been greatly studied, however further study is necessary due to incessant advances in the diagnosis and treatment methods of heart diseases [1-3]. This work is justified as, according to Oliveira et al. [4], the diagonal, lateral and anterosuperior branches are particularly important, due to the frequent use of their epicardial sections in coronary artery bypass surgery, as well as the internal thoracic artery and the saphenous vein.

Among the authors who have researched the subject of the diagonal, lateral and anterosuperior branches of the left ventricle, we must mention: Bianchi [5], Crainicianu [6], Smith [7], James [8], De Paula [9], Mac Alpin et al. [10], Gensini et al. [11], Kalbfleisch \& Hort [12], Carvalho [13], Leguerrier et al. [14], Di Dio \& Rodrigues [15], Henriquez Pino et al. [16] and Baptista et al. [17].

The aim of the present study is to evaluate the frequency and the absolute and relative lengths, but specifically the diâmetro do ramo diagonal, presente em $\mathbf{5 0 \%}$ dos casos, variou de 1,0 a $3,8 \mathrm{~mm}$ (média $2,2 \pm 0,7 \mathrm{~mm}$ ). $\mathrm{O}$ diâmetro do ramo ântero-superior, presente em $84 \%$ dos casos, variou de 1,0 a 4,1 mm (média 2,5 $\pm 0,8 \mathrm{~mm}$ ). Foram encontrados: 30/50 (60\%) casos de dominância da artéria coronária direita, 14/50 (28\%) casos de tipo balanceado e $6 / 12(12 \%)$ casos de dominância da artéria coronária esquerda. A média do fluxo sangüíneo do ramo ântero-superior apresentou valor decrescente nos tipos: dominância da artéria coronária direita, balanceado e dominância da artéria coronária esquerda. Inversamente, o ramo lateral mostrou valor crescente, enquanto o ramo diagonal apresentou maior fluxo no tipo balanceado.

Conclusão: Os resultados demonstraram a complementaridade entre os ramos lateral, diagonal e ânterosuperior, bem como a correlação entre a distribuição dos mesmos e os tipos de circulação coronariana.

Descritores: Coração, anatomia \& histologia. Circulação coronária.

diameter of the diagonal, lateral and anterosuperior branches to determine the co-existence among them. Additionally, the objective of this article is to investigate the possibility of correlation among the distribution of the aforementioned branches in the anterior face of the left ventricle and the three traditional types of circulation: dominance of the right coronary artery, balanced circulation and dominance of the left coronary artery. These three types are based on the analysis of the ramification of the coronary arteries exclusively on the posterior face of the heart [18].

\section{METHOD}

The coronary arteries and their branches in the epicardium of 50 adult cadaver hearts were carefully dissected. They were fixed in $10 \%$ formalin solution and conserved at $5 \%$ formalin solution, in the Anatomy Laboratory of the Life Sciences Center of the Pontifical Catholic University of Campinas.

For each investigated branch (diagonal, lateral and anterosuperior) the length on the surface of the heart was measured, that is, the distance between the root of the branch and its point of penetration into the myocardium. According to Baptista et al. [17] the relative length is calculated as the result of the division between the length of the branch on the heart surface and the length of the left ventricle, considered to be the distance between the point where the left coronary artery splits and the apex of the heart. This result is multiplied by 100 to form a percentage. Each branch was classified as short, medium or long, depending on the relative length being up to $33.3 \%$, from $33.4 \%$ to $66.6 \%$; and more than $66.6 \%$, respectively. 
For the schematic representation of the distribution territory of the studied branches, the heart was viewed from the left pulmonary face with the coronary groove placed horizontally and two transversal lines drawn parallel to the coronary groove to divide the left ventricle into three parts: the upper, middle and lower parts (Figure 1).
A
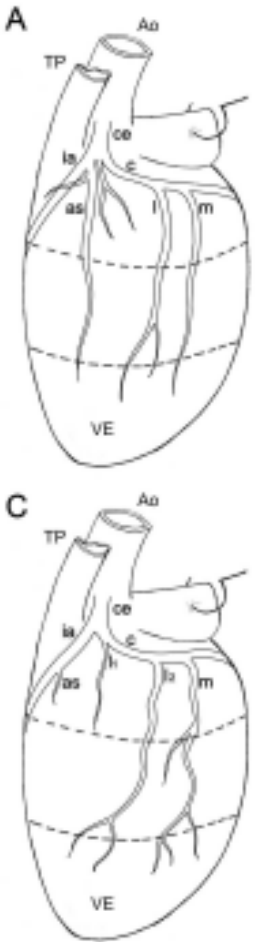

B

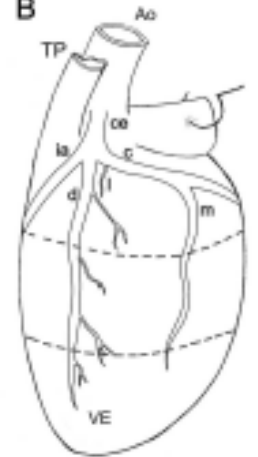

D

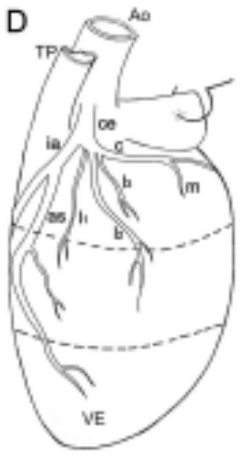

Fig. 1 - Diagram showing the coexistence of the anterosuperior, diagonal and lateral branches from the left side view of the heart (4 cases; in A, B and D - right coronary artery dominance; in $C$ balanced coronary circulation). A. coexistence of the three branches: long anterosuperior (as); short diagonal (d) and long lateral (l). $B$. Coexistence of a long diagonal with a short lateral branch. C. In this case there are two lateral branches, one short (I1) and one long (12), by the side of a short anterosuperior. D. The long anterosuperior branch is by the side of three lateral branches: two medium (l1 and l2) and one short (l3)

$A o=$ aorta $; \mathrm{TP}=$ pulmonary trunk; $\mathrm{VE}=$ left ventricle; $c e=$ left coronary artery; $i a=$ anterior interventricular branch; $c=$ circumflex branch; $m$ = left marginal branch; $c d=$ right coronary artery

The diameters of the diagonal, lateral and anterosuperior branches of the left ventricle were measured at a point near the root of each vessel. The measurements were made using a Mitutoyo digital pachymeter and their sizes were reported as a minimum, maximum, mean and standard deviation. The classification of the arterial supply of the heart in respect to dominance or balance circulation among the coronary arteries was based on the classification of Ortale et al. [18]. The correlation of the blood flow with the diagonal, lateral and anterosuperior arterial branches and the type of coronary artery domination was studied. With the aim of determining the blood flow through the arterial branches, Poiseuille's law was utilized, that is, the blood flow per unit of time is equal to $\alpha \mathrm{x}$ diameter ${ }^{4}$ vessel length. When more than one branch was assessed the sum of the diameters ${ }^{4}$ was considered, for example, two branches with diameters of 2 and $3 \mathrm{~mm}$ would equal $2^{4}+3^{4}$. We did not take into consideration the length of each branch, as the difference of length is practically negligible, according to Souza [19].

\section{RESULTS}

The left coronary artery branch was present in all cases; its diameter varied from 3.3 to $7.4 \mathrm{~mm}$ (mean $5.0 \pm 0.9 \mathrm{~mm}$ ) and its length varied from 7.2 to $20.0 \mathrm{~mm}$ (mean $13 . \mathrm{l} \pm 2.8$ $\mathrm{mm}$ ). In $50 \%$ of the cases there was bifurcation of the left coronary artery into anterior and circumflex interventricular branches. In $46 \%$ of the cases there was trifurcation, with the presence of the anterior, circumflex interventricular and diagonal branches. In $4 \%$ of the cases there were four divisions of the left coronary artery, with the presence of the bifurcated branches and of two diagonal branches.

The diagonal branch was present in 25/50 (50\%) cases, with one branch in 23/25 cases and two branches in 2/25 cases. The anterosuperior branch was present in 42/50 (84\%) cases with one branch in 36/42 cases and two branches in $6 /$ 42 cases. The frequency of the lateral branch was $44 / 50$ (88\%) cases with one branch in 18/44 cases, two branches in 12/44 cases, three branches in 10/44 cases and four branches in $4 / 44$ cases (Figure $1 \mathrm{~A}-\mathrm{D}$ )
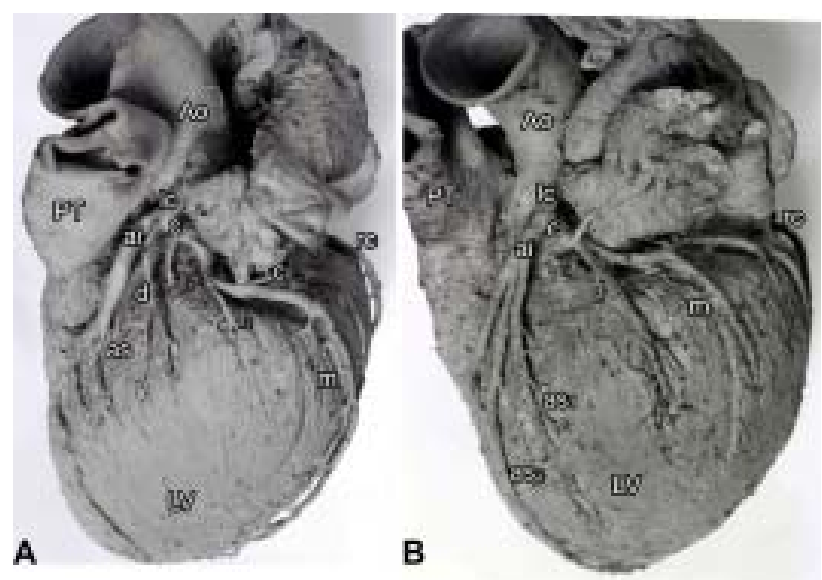

Fig. 2 - Left lateral view of the heart in two cases of right coronary artery dominance. The auricula was removed using a pin A. Anterosuperior branch (as) is short, the diagonal branch (d) is medium and the two lateral branches are short (l1 and l2). B. Two anterosuperior branches, one medium (as1) and one long (as2), are by the side of one lateral branch (l)

$A o=$ aorta $; \mathrm{TP}=$ pulmonary trunk; VE= left ventricle; $c e=$ left coronary artery; ia= anterior interventricular branch; $c=$ circumflex branch; $m=$ left marginal branch; $c d=$ right coronary artery 
Table 1. Distribution of frequency, number of branches, diameters and absolute and relative lengths of the diagonal branch according to the type of dominance

\begin{tabular}{|c|c|c|c|c|c|c|}
\hline Diagonal branch & $\mathrm{nr}$ & $n$ & $\%$ & $\mathrm{D}(\mathrm{mm})$ & $\mathrm{al}(\mathrm{mm})$ & rl(\%) \\
\hline & 0 & 25 & 50 & & & \\
\hline \multirow[t]{2}{*}{ Short } & 1 & 13 & 26 & $1.0-3.82 .1 \pm 0.8$ & $\begin{array}{c}6.6-30.2 \\
21.3 \pm 6.9\end{array}$ & $\begin{array}{c}6.9-31.1 \\
23.3 \pm 7.5\end{array}$ \\
\hline & 2 & 1 & 2 & $\begin{array}{c}1.3-1.5 \\
1.4\end{array}$ & $\begin{array}{c}18.3-24.7 \\
21.5\end{array}$ & $\begin{array}{c}19.2-25.9 \\
22.5\end{array}$ \\
\hline Medium & 1 & 6 & 12 & $\begin{array}{c}1.7-3.4 \\
2.5 \pm 0.6\end{array}$ & $\begin{array}{c}32.5-70.3 \\
41.9 \pm 13.5\end{array}$ & $\begin{array}{c}35.6-68.5 \\
43.5 \pm 12.8\end{array}$ \\
\hline Long & 1 & 4 & 8 & $\begin{array}{c}1.7-3.4 \\
2.6 \pm 0.7\end{array}$ & $\begin{array}{r}55.3-103.7 \\
77.8 \pm 19.5\end{array}$ & $\begin{array}{c}68.9-99.6 \\
82.2 \pm 15.2\end{array}$ \\
\hline Short and medium & 2 & 1 & 2 & $\begin{array}{c}1.5-2.6 \\
2.1\end{array}$ & $\begin{array}{c}12.9-31.4 \\
22.2\end{array}$ & $\begin{array}{c}14.2-34.6 \\
24.4\end{array}$ \\
\hline Total & & 50 & 100 & $\begin{array}{c}1.0-3.8 \\
2.2 \pm 0.7\end{array}$ & $\begin{array}{c}6.6-103.7 \\
35.3 \pm 23.8\end{array}$ & $\begin{array}{c}6.9-99.6 \\
37.6 \pm 23.6\end{array}$ \\
\hline
\end{tabular}

$\mathrm{nr}=$ number of branches; al= absolute length; $\mathrm{rl}$ = relative length

Table 2. Distribution of frequency, number of branches, diameters and absolute and relative lengths of the anterosuperior branch according to the type of dominance

\begin{tabular}{|c|c|c|c|c|c|c|}
\hline Anterosuperior branch & $\mathrm{nr}$ & $n$ & $\%$ & $\mathrm{D}(\mathrm{mm})$ & $\mathrm{al}(\mathrm{mm})$ & rl(\%) \\
\hline & 0 & 8 & 16 & & & \\
\hline \multirow[t]{4}{*}{ Short } & 1 & 20 & 40 & $1.1-3.8$ & 6.1-32.6 & 6.9-32.8 \\
\hline & & & & $2.3 \pm 0.8$ & $20.4 \pm 7.0$ & $22.1 \pm 7.6$ \\
\hline & 2 & 2 & 4 & $1.0-2.9$ & $8.0-27.6$ & $7.7-29.2$ \\
\hline & & & & $1.8 \pm 0.9$ & $17.5 \pm 8.8$ & $18.0 \pm 10.0$ \\
\hline \multirow[t]{4}{*}{ Medium } & 1 & 13 & 26 & $1.2-3.9$ & $28.0-56.2$ & $33.7-63.4$ \\
\hline & & & & $2.8 \pm 0.8$ & $39.9 \pm 7.7$ & $44.3 \pm 8.7$ \\
\hline & 2 & 1 & 2 & $1.9-2.5$ & $48.2-62.1$ & $45.0-57.9$ \\
\hline & & & & 2.2 & 55.2 & 51.4 \\
\hline \multirow[t]{2}{*}{ Long } & 1 & 3 & 6 & $2.9-4.1$ & $64.0-82.5$ & 71.3-82.3 \\
\hline & & & & $3.6 \pm 0.6$ & $70.5 \pm 10.4$ & $77.3 \pm 5.6$ \\
\hline \multirow[t]{2}{*}{ Short and medium } & 2 & 2 & 4 & $1.7-3.2$ & 17.7-57.1 & $20.2-65.2$ \\
\hline & & & & $2.5 \pm 0.4$ & $36.5 \pm 1.3$ & $40.9 \pm 2.5$ \\
\hline \multirow[t]{2}{*}{ Medium and long } & 2 & 1 & 2 & $1.7-2.1$ & $55.0-64.4$ & $63.5-74.4$ \\
\hline & & & & 1.9 & 59.7 & 68.9 \\
\hline \multirow[t]{2}{*}{ Total } & & 50 & 100 & $1.0-4.1$ & 6.1-82.5 & 6.9-82.3 \\
\hline & & & & $2.5 \pm 0.8$ & $32.4 \pm 16.9$ & $35.4 \pm 18.5$ \\
\hline
\end{tabular}

$\mathrm{nr}=$ number of branches; al= absolute length; $\mathrm{rl}$ = relative length 
Table 3. Distribution of frequency, number of branches, diameters and absolute and relative lengths of the lateral branch according to the type of dominance

\begin{tabular}{|c|c|c|c|c|c|c|}
\hline Lateral branch & $\mathrm{nr}$ & $\mathrm{n}$ & $\%$ & $\mathrm{D}(\mathrm{mm})$ & $\mathrm{ca}(\mathrm{mm})$ & $\operatorname{cr}(\%)$ \\
\hline & 0 & 6 & 12 & & & \\
\hline \multirow[t]{8}{*}{ Short } & \multirow[t]{2}{*}{1} & \multirow[t]{2}{*}{13} & \multirow[t]{2}{*}{26} & $1.2-3.7$ & 8.6-30.4 & 10.4-31.6 \\
\hline & & & & $2.1 \pm 0.7$ & $16.5 \pm 7.5$ & $17.6 \pm 7.7$ \\
\hline & \multirow[t]{2}{*}{2} & \multirow[t]{2}{*}{5} & \multirow[t]{2}{*}{10} & $0.7-2.5$ & $4.5-26.9$ & $4.8-28.0$ \\
\hline & & & & $1.4 \pm 0.4$ & $12.1 \pm 3.9$ & $13.0 \pm 3.6$ \\
\hline & \multirow[t]{2}{*}{3} & \multirow[t]{2}{*}{3} & \multirow[t]{2}{*}{6} & $0.6-2.3$ & $6.8-26.8$ & 8.5-30.6 \\
\hline & & & & $1.4 \pm 0.1$ & $17.8 \pm 4.3$ & $19.4 \pm 3.5$ \\
\hline & \multirow[t]{2}{*}{4} & \multirow[t]{2}{*}{2} & \multirow[t]{2}{*}{4} & $1.0-2.4$ & $8.5-27.6$ & $9.4-25.7$ \\
\hline & & & & $1.4 \pm 0.2$ & $16.8 \pm 6.3$ & $17.4 \pm 3.3$ \\
\hline \multirow[t]{4}{*}{ Medium } & \multirow[t]{2}{*}{1} & \multirow[t]{2}{*}{5} & \multirow[t]{2}{*}{10} & $1.0-4.0$ & $29.9-44.8$ & $33.7-47.5$ \\
\hline & & & & $2.3 \pm 1.1$ & $36.9 \pm 6.8$ & $40.7 \pm 5.2$ \\
\hline & \multirow[t]{2}{*}{2} & \multirow[t]{2}{*}{1} & \multirow[t]{2}{*}{2} & 2.0-3.8 & 26.4-32.7 & $33.5-41.4$ \\
\hline & & & & 2.9 & 29.6 & 37.5 \\
\hline \multirow[t]{6}{*}{ Short and medium } & \multirow[t]{2}{*}{2} & \multirow[t]{2}{*}{3} & \multirow[t]{2}{*}{6} & $1.5-2.7$ & 14.3-43.6 & $16.6-57.5$ \\
\hline & & & & $2.2 \pm 0.3$ & $26.1 \pm 2.6$ & $31.4 \pm 6.0$ \\
\hline & \multirow[t]{2}{*}{3} & \multirow[t]{2}{*}{5} & \multirow[t]{2}{*}{10} & $1.0-4.5$ & 4.8-60.6 & 5.7-63.1 \\
\hline & & & & $2.2 \pm 0.4$ & $28.7 \pm 6.1$ & $31.0 \pm 6.1$ \\
\hline & \multirow[t]{2}{*}{4} & \multirow[t]{2}{*}{2} & \multirow[t]{2}{*}{4} & $1.0-2.8$ & $8.1-47.2$ & $8.6-50.0$ \\
\hline & & & & 1.8 & $24.1 \pm 1.1$ & $26.2 \pm 0.3$ \\
\hline Short and long & 2 & 3 & 6 & $1.4-4.5$ & $11.2-84.3$ & 12.3-87.8 \\
\hline \multirow{3}{*}{$\begin{array}{l}\text { Short. medium and } \\
\text { long }\end{array}$} & \multirow{3}{*}{3} & \multirow[t]{3}{*}{2} & 4 & $3.0 \pm 0.1$ & $47.8 \pm 10.8$ & $51.0 \pm 9.9$ \\
\hline & & & & $1.7-4.0$ & $22.0-69.5$ & 24.6-69.3 \\
\hline & & & & $2.6 \pm 0.5$ & $43.5 \pm 4.1$ & $45.8 \pm 0.6$ \\
\hline Total & & 50 & 100 & $0.6-4.5$ & 4.5-84.3 & $4.8-87.8$ \\
\hline & & & & $2.1 \pm 0.7$ & $24.5 \pm 12.3$ & $26.7 \pm 13.1$ \\
\hline
\end{tabular}

$\mathrm{nr}=$ number of branches; al= absolute length; $\mathrm{rl}$ = relative length

The distribution of the frequency, the diameter, the length in the epicardium and the length in respect to the length of the left ventricle, according to the number of branches and the type (short, medium or long) for the diagonal, anterosuperior and lateral branches are shown in Tables 1 to 3 respectively. We detected that for each branch (diagonal, anterosuperior or lateral) the greater the mean diameter of the vessel, the greater was the mean length at the surface of the ventricle and the mean relative length.

In regards to the type of coronary circulation, in 30/50 (60\%) cases the right coronary artery was dominant, in 14/ $50(28 \%)$ cases the dominance was balanced and in 6/50
(12\%) cases the left coronary artery was dominant.

Table 4 shows the frequency of the types of coexistence and diameters of the anterosuperior, diagonal and lateral branches, distributed according to the type of coronary circulation.

Table 5 shows the frequency of the dominant flow branches in the different types of coexistence of the anterosuperior, diagonal and lateral branches and the mean flow of each branch distributed according to the type of coronary circulation. We verified that in $25 / 50$ or $50 \%$ of the cases both the anterosuperior branch and a lateral branch was found, with 15/25 cases of right coronary artery 


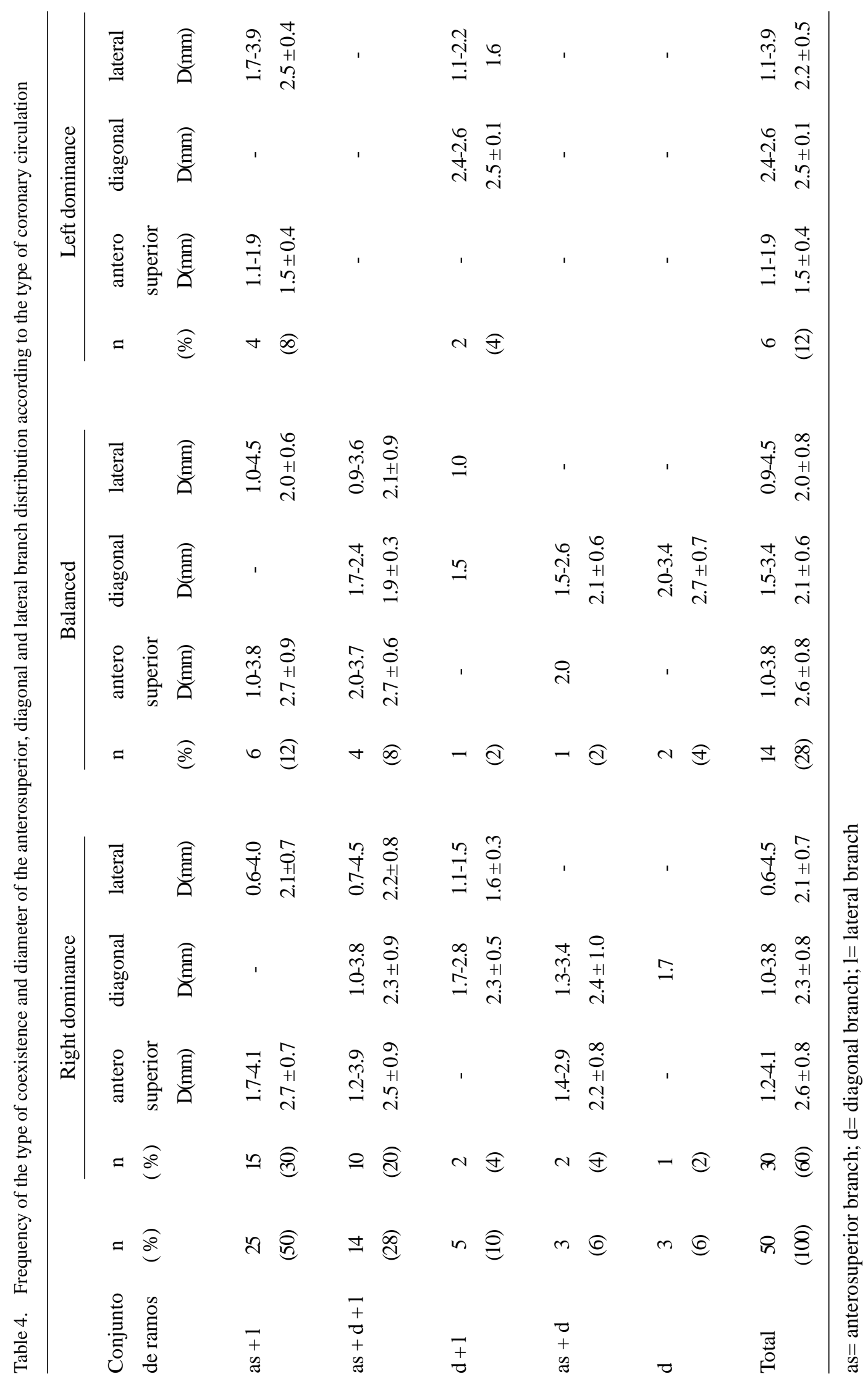


Table 5. Distribution of the dominant branch and the mean flow according to the type of coronary circulation

\begin{tabular}{|c|c|c|c|c|c|c|c|c|c|c|}
\hline \multirow[b]{2}{*}{$\begin{array}{l}\text { Set of } \\
\text { branches }\end{array}$} & \multirow[b]{2}{*}{$\begin{array}{c}n \\
(\%)\end{array}$} & \multicolumn{3}{|c|}{$\begin{array}{l}\text { Right dominance } \\
\text { Dominant branch }\end{array}$} & \multicolumn{3}{|c|}{$\begin{array}{c}\text { Balanced } \\
\text { Dominant branch }\end{array}$} & \multicolumn{3}{|c|}{$\begin{array}{l}\text { Left dominance } \\
\text { Dominant branch }\end{array}$} \\
\hline & & $\begin{array}{c}\text { antero } \\
\text { superior }\end{array}$ & diagonal & lateral & $\begin{array}{l}\text { antero } \\
\text { superior }\end{array}$ & diagonal & lateral & $\begin{array}{c}\text { antero } \\
\text { superior }\end{array}$ & diagonal & lateral \\
\hline as +1 & $\begin{array}{l}25 \\
(50)\end{array}$ & 9 & - & 6 & 4 & - & 2 & - & - & 4 \\
\hline as $+d+l$ & $\begin{array}{c}14 \\
(28)\end{array}$ & 5 & 3 & 2 & 3 & - & 1 & - & - & - \\
\hline$d+l$ & $\begin{array}{c}5 \\
(10)\end{array}$ & - & 2 & - & - & 1 & - & - & 2 & - \\
\hline as $+d$ & $\begin{array}{c}3 \\
(6)\end{array}$ & 1 & 1 & - & - & 1 & - & - & - & - \\
\hline d & $\begin{array}{c}3 \\
(6)\end{array}$ & - & 1 & - & - & 2 & - & - & - & - \\
\hline Total & $\begin{array}{c}50 \\
(100)\end{array}$ & 15 & 7 & 8 & 7 & 4 & 3 & 0 & 2 & 4 \\
\hline
\end{tabular}

\begin{tabular}{|c|c|c|c|c|c|c|c|c|c|}
\hline \multirow{3}{*}{$\begin{array}{l}\text { Mean blood } \\
\text { flow of the } \\
\text { branch }\left(\mathrm{mm}^{4}\right)\end{array}$} & \multicolumn{3}{|c|}{ Right dominance } & \multicolumn{3}{|c|}{ Balanced } & \multicolumn{3}{|c|}{ Left dominance } \\
\hline & $\begin{array}{c}\text { antero } \\
\text { superior }\end{array}$ & diagonal & lateral & $\begin{array}{c}\text { antero } \\
\text { superior }\end{array}$ & diagonal & lateral & $\begin{array}{l}\text { antero } \\
\text { superior }\end{array}$ & diagonal & lateral \\
\hline & 67.83 & 27.16 & 69.86 & 64.94 & 19.15 & 71.98 & 2.75 & 13.16 & 108.56 \\
\hline
\end{tabular}

as= anterosuperior branch; $\mathrm{d}=$ Diagonal branch; $\mathrm{l}=$ Lateral branch

dominance, 9/15 anterosuperior branch dominance and in $6 / 15$ cases lateral branch dominance. In 6/25 cases of balanced circulation, the anterosuperior branch was dominant in 4/6 cases and the lateral branch was dominant in 2/6 cases. In all the $4 / 25$ cases of left dominance, the dominant branch was the lateral branch. In respect to the mean blood flow, the anterosuperior branch presented a decreasing flow, in right dominance and balanced circulation and left dominance, respectively, while the lateral branch showed an increasing value respectively and the diagonal branch presented greater flow in the balanced circulation. These outcomes demonstrate the coexistence among these three coronary branches. Consequently, the greater the blood flow of the lateral branch, the longer was the length of the circumflex branch of the left coronary artery in the diaphragmatic face of the heart.

\section{COMMENTS}

The length of the left coronary artery trunk is important for the cannulae used in myocardial perfusion, during aortic valve surgery [1,2]. In our results, the length was from 7.2 to $20.0 \mathrm{~mm}$ (mean of $13.1 \pm 2.8 \mathrm{~mm}$ ), values practically identical to those reported by Henriquez Pino et al. [16] and a mean value a little greater than the one reported by Kronzon et al. [20]. These authors established a correlation between significantly shorter left coronary artery lengths and left dominance and balanced circulation, when compared with 
patients with right coronary artery dominance. We did not confirm this correlation.

Our outcomes showed the left coronary artery was bifurcated in $50 \%$ of the cases, giving only anterior and circumflex interventricular branches, in $46 \%$ of the cases it had three divisions with an addition of the diagonal branch and in $4 \%$ of the cases four divisions with two diagonal branches. These percentages are intermediate to those found by Banchi [5], Crainicianu [6], De Paula [9], Leguerrier et al. [14], Henriquez Pino et al. [16] and Baptista et al. [17].

Table 6. Variations of the lengths of the diagonal, anterosuperior and lateral branches in the left ventricle epicardium

\begin{tabular}{|c|c|c|c|c|}
\hline & $\begin{array}{l}\text { Baptista et al. } \\
\text { (1991) }\end{array}$ & Current study & & \\
\hline $\begin{array}{l}\text { Absolute length } \\
(\mathrm{mm})\end{array}$ & $\begin{array}{c}\text { Diagonal Branch } \\
\text { (\%) }\end{array}$ & $\begin{array}{c}\text { Diagonal Branch } \\
\text { (\%) }\end{array}$ & $\begin{array}{c}\text { Antero-superior } \\
\text { Branch (\%) }\end{array}$ & $\begin{array}{c}\text { Lateral Branch } \\
\text { (\%) }\end{array}$ \\
\hline Less than 10 & 1.3 & 4.0 & 4.8 & 6.8 \\
\hline 10.1 a 20.0 & 7.8 & 16.0 & 19.0 & 36.4 \\
\hline 20.1 a 30.0 & 27.3 & 36.0 & 28.6 & 31.8 \\
\hline 30.1 a 40.0 & 39.0 & 20.0 & 23.8 & 11.4 \\
\hline 40.1 a 50.0 & 13.0 & 4.0 & 9.5 & 9.1 \\
\hline 50.1 a 60.0 & 5.2 & 4.0 & 7.1 & 4.5 \\
\hline 60.1 a 70.0 & 2.6 & 4.0 & 4.8 & - \\
\hline 70.1 a 80.0 & 1.3 & 4.0 & - & - \\
\hline 80.01 a 90.0 & 1.3 & 4.0 & 2.4 & - \\
\hline 90.1 a 100.0 & - & - & - & - \\
\hline Greater than 100 & 1.3 & 4.0 & - & - \\
\hline Total & & 100.0 & 100.0 & 100.0 \\
\hline
\end{tabular}

Table 7. Variations of the lengths of the diagonal, anterosuperior and lateral branches in respect to the left ventricle

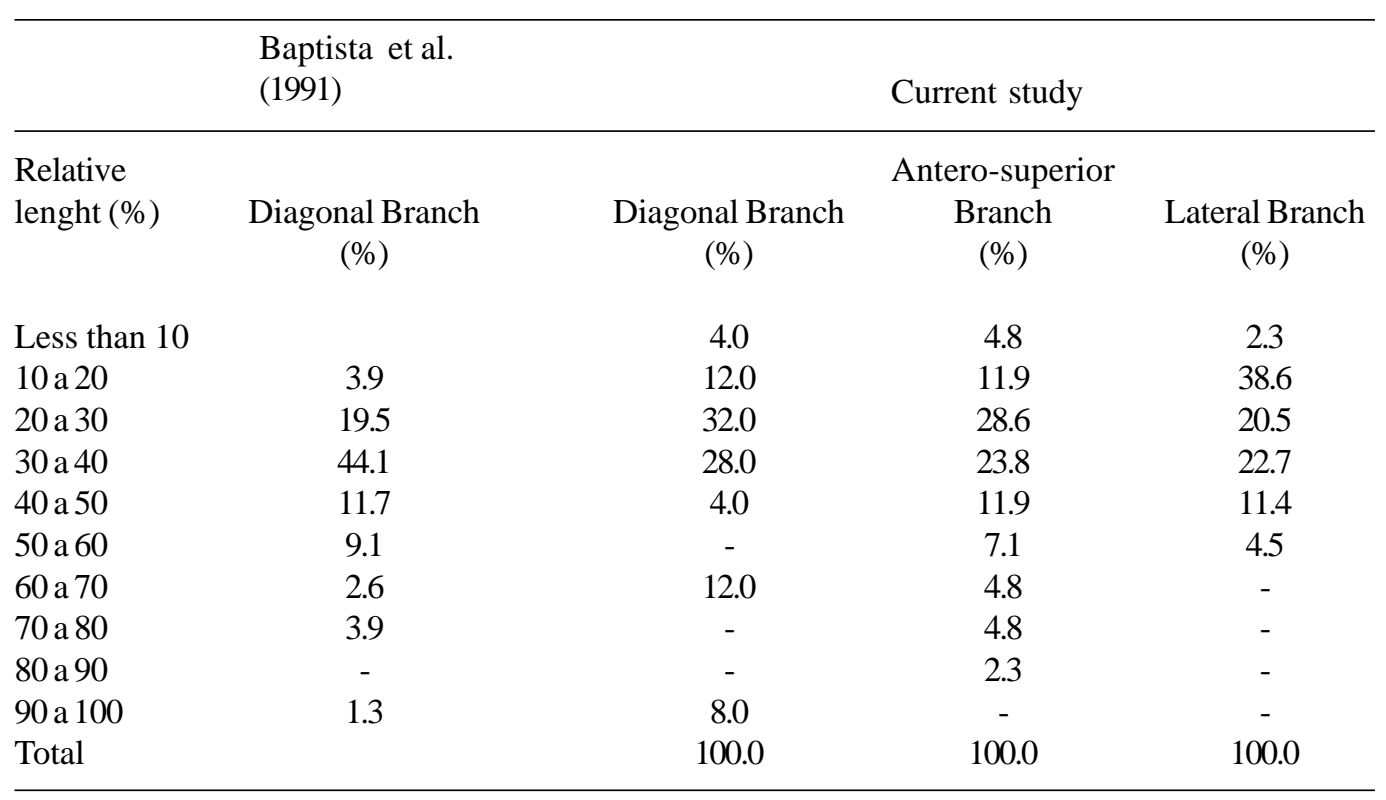


The diagonal branch was baptized of diagonal artery by Crainicianu [6]. We identified one diagonal branch in $46 \%$ of the cases and two branches in $4 \%$ of the cases, frequencies very close to those reported by Baptista et al. [17] who found $46.1 \%$ and $7.5 \%$, respectively.

According to these authors, the variation in length of the diagonal branch is significant in heart surgery, due to the use of its external portion in the implantation of saphenous vein grafts in coronary artery bypass grafting. In our results, the length of the diagonal branch was consistent with the lengths of these authors. The relative length ranged from $6.9 \%$ to $99.6 \%$ (mean $38.8 \%$ ) however, on average the diagonal branch reaches the middle third of the left ventricle, as reported by Baptista et al. [17] and De Paula [9]. Tables 6 and 7 show the distribution of the absolute length and the relative length of the external part of the diagonal branch at $10-\mathrm{mm}$ intervals respectively, giving similar to the results to Baptista et al. [17]. In these tables, we added data concerning at variation of the length of the anterosuperior and lateral branches at $10-\mathrm{mm}$ intervals.

The anterosuperior branch of the left ventricle was so denominated by Baptista et al. [21] due to its origin in the anterior interventricular branch in the upper third of the left ventricle, to differentiate it from the branches that originate from the lower and middle thirds. Banchi [5] denominated all of them descending collateral branches.

The circumflex branch, before giving rise to the marginal branch, derives the lateral branch, which was denominated the lateral artery for the first time by Leguerrier et al. [14]. Banchi [5] denominated it the left ventricle anterior branch, the name used by Smith [7]. The length of the lateral branch on the surface of the ventricle ranged from 4.5 to $84.3 \mathrm{~mm}$ (mean: $24.5 \pm 12.3 \mathrm{~mm}$ ), which is $30 \mathrm{~mm}$ longer than that reported by Leguerrier et al. [14]. According to these authors, normally there was a delicate 2 to 3-mm thick myocardial bridge that easily allowed arteriotomy during surgery. We did not find any myocardial bridge in the lateral or anterosuperior branches. In only two cases we identified bridges on the diagonal branch, in one case it was $70.3 \mathrm{~mm}$ in length covered by a bridge of $29.6 \mathrm{~mm}$ and in the other it was $89.0 \mathrm{~mm}$ with a bridge of $9.5 \mathrm{~mm}$.

According to Leguerrier et al. [14] the lateral branch had a diameter of more than $1.5 \mathrm{~mm}$ in $82.1 \%$ of the cases which made the implantation of a saphenous graft for coronary artery bypass grafting possible. In our cases, the diameter of the lateral branch ranged from 0.6 to $4.5 \mathrm{~mm}$ (mean $2.1 \pm$ $0.7 \mathrm{~mm}$ ) and was greater than $1.5 \mathrm{~mm}$ in $38 / 44$ cases. In respect to the anterosuperior and diagonal branches, in our series the diameters were greater than $1.5 \mathrm{~mm}$ in 36/42 and 21/25 cases, respectively, which according to Leguerrier et al. make coronary artery bypass grafting possible [14].

In respect to the coronary circulation, a dominance of the right coronary artery was seen in $60 \%$ of the cases, balanced circulation in $28 \%$ and left coronary artery dominance in $12 \%$ of the cases, percentages similar to those reported by Hadziselimovic et al.[12], (63\%, 24\% and 13\%, respectively).

According to the Kalbfleisch \& Hort [12], there is a small correlation between the diameter of the coronary artery and the myocardial area it supplies, which is in agreement with Poiseuille's law, that says that the blood flow is proportional to the fourth power of the diameter of the vessel (diameter ${ }^{4}$ ). We calculate the flow in each type of coronary circulation and identified coexistence among the studied branches. This coexistence was suggested by Banchi [5] and De Paula [9]. In respect to the relationship among the coexistence of the branches and the type of coronary circulation, we verified that, as the flow in the lateral branch increased from right coronary artery dominance, balanced circulation and left coronary artery dominance, the anterosuperior branch decreased with the diagonal branch presenting with higher arterial flow in the balanced circulation.

\section{CONCLUSIONS}

We came to the following conclusions:

a) The frequencies of the lateral, anterosuperior and diagonal branches seen in this study were $88 \%, 84 \%$ and $50 \%$, respectively;

b) The greater the diameter of the lateral, anterosuperior or diagonal branches, the greater was their length in the epicardium;

c) There was coexistence among the diagonal and anterosuperior or lateral branches in the arterial irrigation of the left ventricle;

d) A simple observation of the lateral, diagonal and anterosuperior branches in the anterior face of the left ventricle, allows a prediction of the type of coronary circulation: right coronary artery dominance, balance circulation or left coronary artery dominance, classically obtained by an analysis of the arteries exclusively in the posterior face of the heart.

\section{ACKNOWLEDGEMENTS}

Ana Maria Ferreira Paccola received a grant from the Scientific Initiation Program of the Foundation in Support of Scientific Research from the Pontifical Catholic University in Campinas. 


\section{BIBLIOGRAPHIC REFERENCES}

1. Green GE, Bernstein S, Reppert EH. The length of the left main coronary artery. Surgery. 1967;62(6):1021-4.

2. Fox C, Davies MJ, Webb-Peploe MM. Length of left main coronary artery. Br Heart J. 1973;35(8):796-8.

3. Falci Jr. R, Prates NEVB. Anatomia das artérias coronárias. Rev Med. 1994;72(1/4):21-4.

4. Oliveira SA, Lemos PCP, Dallan LAO. Cirurgia das artérias coronárias. In: Goffi FS, editor. Técnica cirúrgica: bases anatômicas, fisiopatológicas e técnicas da cirurgia. 4a ed. São Paulo:Atheneu;1996. p.422-33.

5. Banchi A. Morfologia delle arteriae coronariae cordis. Arch Ital Anat Embriol. 1904;3:87-164.

6. Crainicianu A. Anatomische studien über die coronaraterien und experimentelle untersuchungen über die durchgängigkeit. Virch Arch Path Anat. 1922;238:1-75.

7. Smith GT. The anatomy of the coronary circulation. Am J Cardiol. 1962;9(Suppl.):327-42.

8. James TN. Anatomy of the coronary arteries in health and disease. Circulation. 1965;32(3):1020-33.

9. De Paula W. Estudo estatístico sobre irrigação coronariana no coração humano em brancos e negros. Fol Clin Biol. 1972;1(1):18-40.

10. MacAlpin RN, Abbasi AS, Grollman Jr. JH, Eber L. Human coronary artery size during life: a cinearteriographic study. Radiology. 1973;108(3):567-76.

11. Gensini GG, Manfroi WC, Kelly A. International angiographic nomenclature of the human coronary circulation. Arq Bras Cardiol. 1976;29(3):171-4.
12. Kalbfleisch H, Hort W. Quantitative study on the size of coronary artery supplying areas postmortem. Am Heart J. 1977;94(2):183-8.

13. Carvalho RG. Nomenclatura das artérias coronárias. Arq Bras Cardiol. 1978;31(6):415-20.

14. Leguerrier A, Bourgin T, Marcade E, Duval JM, Rioux C, Logeais $\mathrm{Y}$ et al. Les branches ventriculaires de l'artère circonflexe du coeur. Bull Assoc Anat. 1980;64(186):415-23.

15. Di Dio LJA, Rodrigues H. Cardiac segments in the human heart. Anat Clin. 1983;5:115-24.

16. Henriquez Pino J, Riffo EO, Vargas FM, Vargas JE. Dispositión de las ramas arteriales ventriculares en corazones de individuos chilenos. An Anat Norm. 1987;5(5):67-72.

17. Baptista CA, Di Dio LJ, Prates JC. Types of division of the left coronary artery and the ramus diagonalis of the human heart. Jpn Heart J. 1991;32(3):323-35.

18. Ortale JR, Keiralla LC, Sacilotto L. The posterior ventricular branches of the coronary arteries in the human heart. Arq Bras Cardiol. 2004;82(5):468-72.

19. Sousa OM. Anatomia topográfica: parte geral. 3a ed. São Paulo:Rossolillo;1970. p.142-7.

20. Kronzon I, Deutsch P, Glassman E. Length of the left main coronary artery: its relation to the pattern of coronary arterial distribution. Am J Cardiol. 1974;34(7):787-9.

21. Baptista CA, Di Dio LJ, Davis JT, Teofilovski-Parapid G. The cardiac apex and its superficial blood supply. Surg Radiol Anat. 1988;10(2):15-60.

22. Hadziselimovic H, Dilberovic F, Ovcina F. Blood vessels of the human heart: coronarography and dissection. Acta Anat. 1980;106(4):443-9. 